\title{
Intima media thickness, pulse wave velocity, and flow mediated dilation
}

\author{
Rosa Maria Bruno', Elisabetta Bianchini ${ }^{1}$, Francesco Faita', Stefano Taddei ${ }^{2}$ and Lorenzo Ghiadoni ${ }^{2 *}$
}

\begin{abstract}
The identification of vascular alterations at the sub-clinical, asymptomatic stages are potentially useful for screening, prevention and improvement of cardiovascular risk stratification beyond classical risk factors.

Increased intima-media thickness of the common carotid artery is a well-known marker of early atherosclerosis, which significantly correlates with the development of cardiovascular diseases. More recently, other vascular parameters evaluating both structural and functional arterial proprieties of peripheral arteries have been introduced, for cardiovascular risk stratification and as surrogate endpoints in clinical trials. Increased arterial stiffness, which can be detected by applanation tonometry as carotid-femoral pulse wave velocity, has been shown to predict future cardiovascular events and to significantly improve risk stratification.

Finally, earlier vascular abnormalities such as endothelial dysfunction in the peripheral arteries, detected as reduced flow-mediated dilation of the brachial artery, are useful in the research setting and as surrogate endpoints in clinical trials and have also been suggested for their possible clinical use in the future.

This manuscript will briefly review clinical evidence supporting the use of these different vascular markers for cardiovascular risk stratification, focusing on the correct methodology, which is a crucial issue to address in order to promote their use in future for routine clinical practice.
\end{abstract}

Keywords: Carotid artery, Intima-media thickness, Arterial stiffness, Pulse wave velocity, Endothelium, Flow-mediated dilation

\section{Introduction}

Cardiovascular (CV) disease is the main cause of mortality and morbidity worldwide [1]. It has been suggested that risk estimation by classical risk factors (blood pressure, glucose, cholesterol) and circulating biomarkers may fail to adequately predict the risk of $\mathrm{CV}$ events because their fluctuations over time represent many transient and partial "snapshots" rather than a reliable picture of a complex situation developing over decades [2]. Conversely, imaging biomarkers of vascular damage might integrate the longlasting cumulative effects of all traditional and nonidentified $\mathrm{CV}$ risk factors and can be detected as target organ damage before clinical events occur, at a stage when interventions may be effective. For that reason, some of these biomarkers are recommended by international

\footnotetext{
* Correspondence: I.ghiadoni@med.unipi.it

${ }^{2}$ Department of Clinical \& Experimental Medicine, University of Pisa, Via Roma, 67560110 Pisa, Italy

Full list of author information is available at the end of the article
}

scientific societies for the improvement of $\mathrm{CV}$ risk stratification $[3,4]$.

Recently, the concept of early vascular aging was introduced to describe structural and functional changes occurring in the large arteries with aging, which are accelerated in individuals at increased CV risk [5]. It can be measured by non-invasive techniques, and includes diffuse intimal thickening, usually measured as carotid intimamedia thickness (C-IMT) [6], aortic stiffening, evaluated as carotid -femoral pulse wave velocity (cfPWV) [7], and endothelial dysfunction, commonly measured as brachial artery flow-mediated dilatation (FMD) [8,9].

Increased C-IMT is an intermediate stage in the continuum of atherosclerosis, which significantly correlates with coronary and cerebrovascular disease $[10,11]$. Other vascular parameters evaluating structural and functional arterial proprieties of peripheral arteries were then introduced. Increased cfPWV is already considered a subclinical target organ in hypertensive patients [4], since it has been shown to predict future cardiovascular events [12] 
and improve reclassification to a higher risk category [13]. Earlier vascular abnormalities, such as impaired FMD $[8,9]$, have also been suggested for their potential use for risk prediction.

This review will focus on how to proceed to obtain accurate and reliable assessment of these vascular markers, improving their predictive value for the future use in clinical practice.

\section{Carotid intima-media thickness}

C-IMT is measured by high resolution B-mode ultrasound of extra-cranial carotid arteries and it is the most widely accepted non-invasive marker of subclinical atherosclerosis [6,14]. C-IMT is considered an intermediate phenotype of atherosclerosis suitable for use in large-scale population studies [15], since its increase has been associated with higher cardiovascular risk $[16,17]$ and with the presence of advanced stage of atherosclerosis in peripheral, cerebral and coronary arteries [18,19]. Epidemiological studies consistently reported a predictive value of increased C-IMT for myocardial infarction and stroke, independent of traditional CV factors [10,20-25], which has been confirmed in a meta-analysis of 12 relevant general population-based studies [26]. For these reasons, C-IMT is included in the in European Society of Hypertension guidelines as target organ damage (class II, level B) in hypertensive patients [4]. However, based on the results of a single study, the MESA [27], C-IMT is no longer recommended in the 2013 ACC/AHA Guideline on the assessment of Cardiovascular Risk [28].

C-IMT detected by high-resolution ultrasound represents the combined width of the intima and media, which are technically indistinguishable. C-IMT in healthy subjects consists almost entirely of media, with a progressive intimal thickening or medial hypertrophy determined by age, gender and hypertension, which do not necessarily reflect the atherosclerotic process [29].

The carotid artery is classified into three segments when undergoing ultrasound study, each approximately $1 \mathrm{~cm}$ in length. The most proximal segment, the common carotid (CCA) represent the 1-cm straight segment prior identified by a divergence of the near and far walls as the artery begins to divide into its internal and external branches. This focal widening of bifurcation extends over approximately $1 \mathrm{~cm}$ and is labeled the carotid bulb (CB). The tip of the flow divider separating the diverging internal carotid artery (ICA) and external carotid artery defines its distal margin; the final segment is the proximal $1 \mathrm{~cm}$ of the ICA. The CCA far wall is the easiest segment to be examined and the most commonly used measurement in clinical studies, resulting in a better prediction of stroke than myocardial infarction [11,30]. Several studies suggest the CCA far wall as the best location in terms of feasibility and reproducibility of C-
IMT measure $[31,32]$. Nevertheless, it has been also suggested C-IMT measurements at multiple angles of both the near and far walls might provide the best balance between reproducibility, rate of C-IMT progression, treatment effect and their associated precision in this low-risk population with subclinical atherosclerosis [33].

Despite it has been proposed that a slower progression of C-IMT might be associated with a reduction in $\mathrm{CV}$ events [34], a meta-analysis including 41 trials with 18,307 participants showed no significant relationship between $\mathrm{C}$-IMT regression and events, suggesting that regression or slowed progression of C-IMT, induced by CV drug therapies, may not reflect a reduction in CV events [35]. However, it has to be acknowledged that the estimation of C-IMT in the vast majority of the studies was obtained manually by calipers, without the use of an automatic approach for the measurement. Therefore, accuracy of CIMT and, particularly, of its changes over time is not simply a methodological question but might have important consequences in the clinical setting. B-mode image processing-based devices (Figure 1) and radio-frequency (RF)-based echo-tracking systems are now widely available and should definitely be adopted to increase precision and accuracy. RF-based devices are considered very accurate since they are based on signals with higher spatial resolution than B-mode data [36,37]. However, robust image-based systems have been recently validated, showing similar reproducibility $[38,39]$. These systems require high quality of the scans and standardized system settings (e.g. dynamic range, depth gain set or filtering) [40], that should clearly reported, especially for follow-up studies [41]. The reliability of B-mode based systems has been recently acknowledged by the scientific community, since measures obtained by this technique were used for the definition of C-IMT reference values obtained by echotracking [42]. C-IMT reference values were obtained by echo-tracking in a cohort of 24871 individuals from 24 research centers worldwide [42], and allowed estimation of C-IMT age- and sex-specific percentiles in a healthy population of the 4234 individuals without CV disease, $\mathrm{CV}$ risk factors, and blood pressure-, lipid-, and/or glucose-lowering medication. These reference values will favor the use of C-IMT assessment in clinical practice, possibly for a better risk classification particularly concerning C-IMT modifications over time.

\section{Pulse wave velocity}

Arterial distensibility is a measure of the artery's ability to expand and contract with cardiac pulsation and relaxation. Aging, hypertension and other risk factors can alter the structural and functional properties of the arterial wall, leading to a decrease in arterial distensibility, which seems to be a common pathologic mechanism among CV diseases [37]. The aorta is a major vessel of interest when 


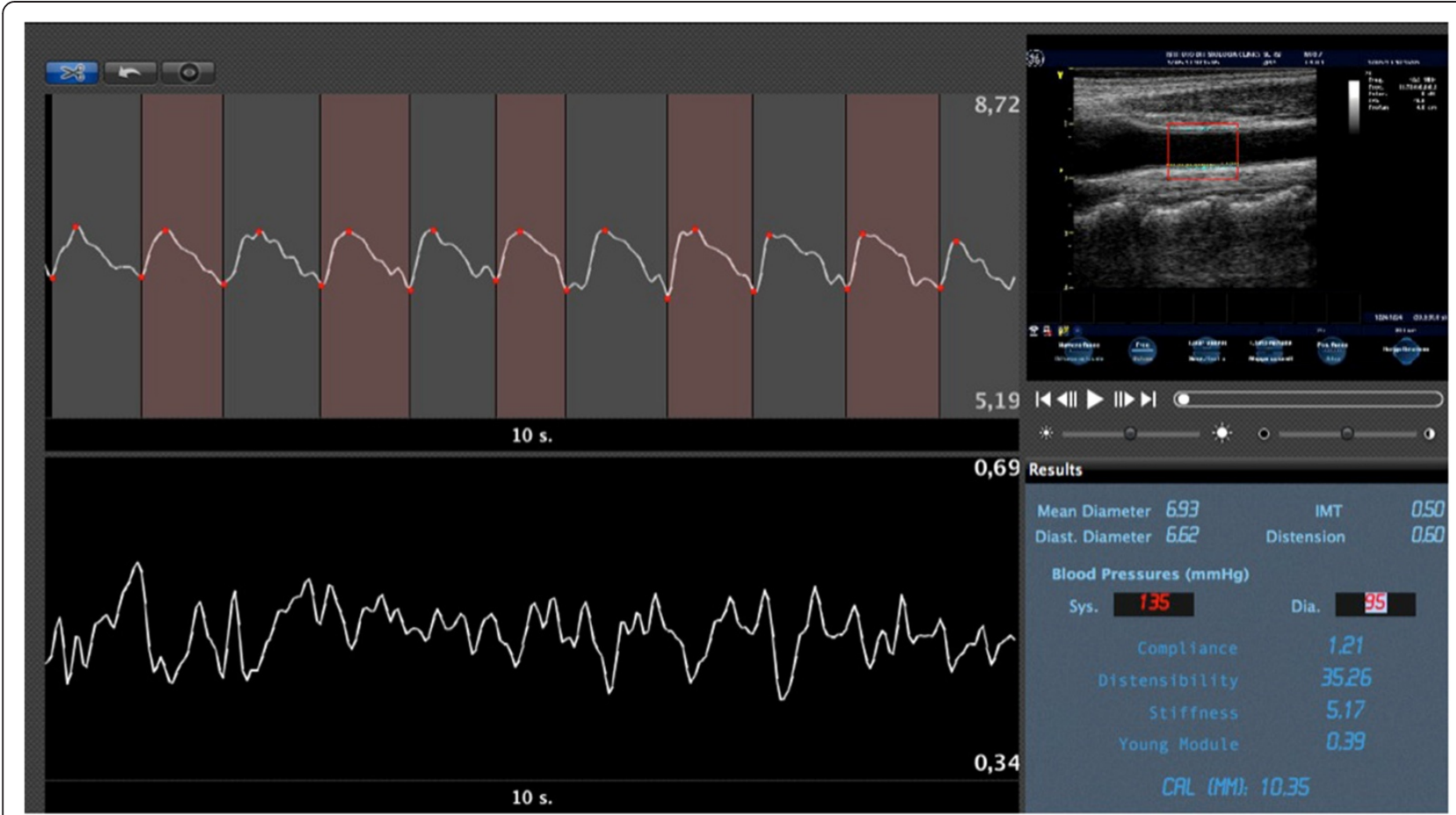

Figure 1 Example of automatic edge detection of intima-media thickness (IMT) and diameter on B-mode scan of a common carotid artery (top right). Graph shows changes over cardiac cycles of diameter (top) and IMT (bottom). The panel on bottom left reports mean values of diameter, IMT and some parameter of carotid stiffness.

determining arterial stiffness, since thoracic and abdominal aorta makes the largest contribution to the arterial buffering function [37]. Elastic properties of conduit arteries vary along the arterial tree, with proximal arteries being more elastic and distal ones stiffer. Aging, along with blood pressure, is the main determinant of stiffness in both carotid and aortic stiffness [43,44], inducing a reduced synthesis and an increased degradation of elastin, and on the other hand to an increased synthesis and reduced degradation of type 1 and type 3 collagen [45].

Aortic degeneration is responsible for most of the pathophysiologic effects of central pressure and arterial stiffness on the left ventricle, brain, and kidney $[5,7,37]$. The assessment of PWV is considered to be the "gold standard" measurement of aortic stiffness, as it is a simple, non-invasive and reproducible method and has the largest amount of clinical evidence, providing the predictive value of aortic stiffness for CV events [12].

PWV can be measured from various arterial sites: the pressure waveforms are usually obtained trans-cutaneously at the common carotid artery and the femoral artery. The distance covered by the waves is assimilated to the surface distance between the two recording sites, and the time delay (or transit time) measured between the feet of the two waveforms is estimated. PWV is then calculated as the ratio of the distance to the time delay: $P W V=$ (distance) transit time) (Figure 2).
Distance has to be measured precisely, since small inaccuracies may influence the absolute value of PWV [46]. Inaccurate distance measurements might occur with abdominal obesity, particularly in men [47]. In the past decade, different modalities for aortic path estimation have been used, leading to heterogeneous and noncomparable results among different research groups, but very recently, accumulation of data using magnetic resonance imaging allow the definition of a shared methodology in all the laboratories [48].

Transit time is commonly estimated by the foot-tofoot method (Figure 2). The foot of the wave is defined at the end of diastole, when the steep rise of the wave front begins. The transit time is the time of travel of the foot of the wave over a known distance.

The most accepted methods for cfPWV measurement are those using mechano-transducers or applanation tonometers (Figure 2). Pressure waveforms can be recorded simultaneously to provide automated measurement of PWV as with the Complior System (Colson, Les Lilas, France) which employs dedicated mechano-transducers directly applied on the skin [49]. The transit time is determined by means of a correlation algorithm between each simultaneous recorded wave. Pressure waves can also be recorded sequentially from different sites by a single highfidelity applanation tonometer, and transit time calculated using registration with a simultaneously recorded ECG, 


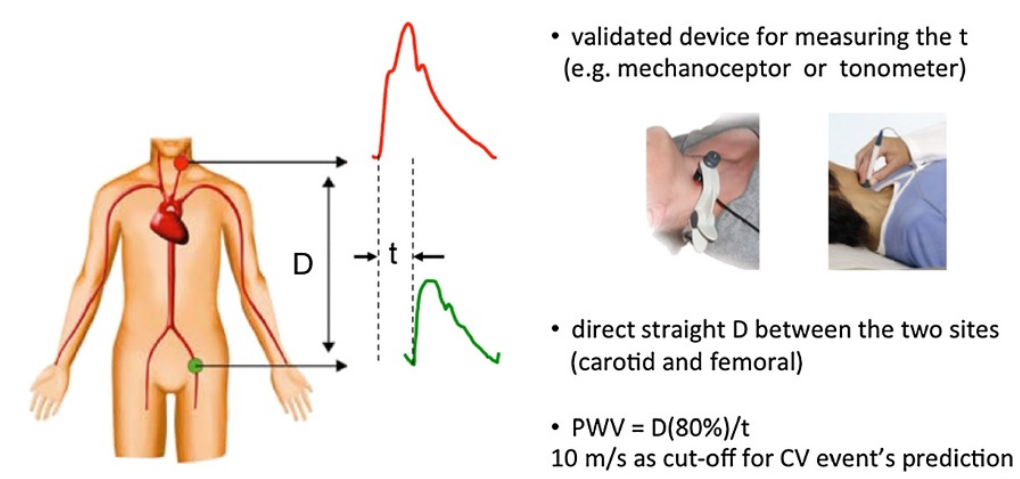

Figure 2 Figure shows a schematic representation of pulse wave velocity (PWV) according to current international recommendations [48]. Pulse wave travel time: t; distance: D; CV: cardiovascular.

such as with the SphygmoCor system (AtCor, Sydney, Australia) [50]. Brachial-ankle pulse-wave velocity (baPWV) has been suggested as a simpler alternative to cf-PWV, since the aortic PWV was the main independent correlate of baPWV, followed by leg PWV [51]. Finally, the distension waves obtained at a short time interval at two arterial sites (common carotid and femoral artery, for instance) by high-resolution echo-tracking devices can be also used to calculate PWV, using the R-wave of the ECG for calculating the time delay [37].

In 2010 the Reference Value for Arterial Stiffness Collaboration provided normal and reference values for cfPWV, calculated using a standardized methodology in a large European population (data from 16867 individuals and patients from 13 different centers across 8 European countries) [52]. Values were defined in a 'normal' population of individuals having optimal blood pressure values and no additional CV risk factors, whereas 'reference' values were identified in individuals or patients presenting CV risk factors. For normal and reference values, the population was categorized according to age decade and BP category.

As already mentioned, current hypertension guidelines include cfPWV in the list of factors influencing the prognosis of hypertensive patients: a threshold cfPWV value of greater than $10 \mathrm{~m} / \mathrm{s}$ is considered as an index of large artery stiffening and an indicator of sub-clinical organ damage [4]. This value derives from a standardized calculation for PWV, which takes into consideration the most accurate approximation of the distance between the carotid and femoral artery [48]. However, it is still discussed whether this threshold or a series of threshold values (such as $>90$ th percentile or $>75$ th percentile of normal values for PWV dependent upon age) would be more accurate reference values for identifying people at increased CV risk [53].

\section{Flow-mediated dilation}

Endothelium plays a primary role in the control of vascular function and structure, by production and release of nitric oxide $(\mathrm{NO})$ under the influence of agonists and by mechanical forces, such as shear stress [54]. NO not only cause vasodilation, but also inhibits key mechanisms of vascular damage, such as platelet aggregation, vascular smooth muscle cell proliferation and migration and monocyte adhesion [54,55]. Despite its key importance in vascular pathophysiology, NO can be hardly assayed directly, for its biochemical properties. For this reason, several indirect methods for assessing stimulated NO release, and thus endothelial function, have been developed [9,56,57].

Endothelial function in clinical research is usually tested by vascular reactivity studies [56], measuring the degree of vasodilation as the changes in diameter induced by specific stimuli in the macrocirculation (e.g. in the epicardial or brachial arteries) and the microcirculation (coronary, peripheral muscle, subcutaneous and skin microcirculation).

FMD is a non-invasive method, introduced in 1992 [58], which is based on the measurement of brachial artery diameter changes after an increase in shear stress induced by reactive hyperemia (Figure 3 ). The NO-dependency of FMD has been documented invasively with intra-arterial infusion of by $\mathrm{N}^{\mathrm{G}}$-mono-methyl-L-arginine (L-NMMA), a specific inhibitor of NO synthase, which reduced of almost $2 / 3$ the dilation of the artery (radial or brachial) in response to shear stress $[59,60]$.

Available data indicate that impaired FMD is associated with almost every condition predisposing to atherosclerosis and $\mathrm{CV}$ disease, as a putative intermediate step for the development of subclinical target organ damage and later clinical events. Cross-sectional studies have shown a correlation between FMD and C-IMT $[61,62]$ and C- IMT progression over a 6-year follow- up in a population free of cardiovascular disease [63] or after 1 year, in hypertensive, postmenopausal women [64]. Impaired FMD has been shown to be an independent predictor of in-stent stenosis after single-vessel coronary interventions [65]. In the setting of primary prevention, most of the studies showed that FMD is predictive of cardiovascular events 


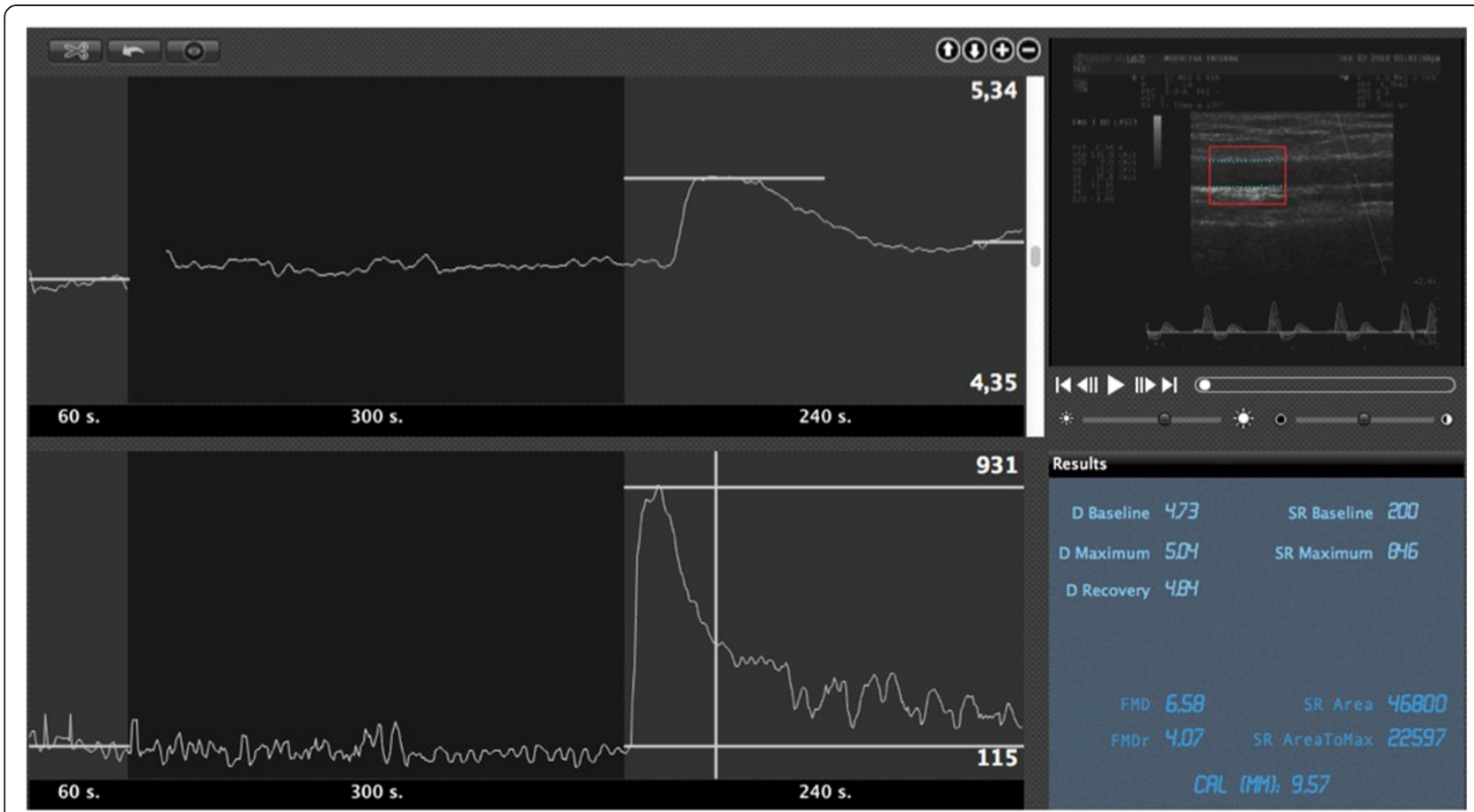

Figure 3 Example of automatic edge detection and real-time analysis of B-mode and doppler signal during flow mediated dilation (FMD) assessment (top right). Graphs show changes in brachial artery diameter diameter ( $D$, top panel) and shear rate (SR, left). The panel on bottom left reports mean baseline, maximun) values of $D$ and $S R$, and the computation of FMD.

beyond traditional risk factors in special subsets of patients such as after elective vascular surgery [66], in patients with chest pain [67], in hypertensive patients $[68,69]$ and in large population studies [70,71]. A recent metaanalysis summarized the results of four population-based cohort studies, and ten cohort studies, involving 5,547 participants, showing a pooled relative risk of cardiovascular events per $1 \%$ increase in brachial FMD, adjusted for confounding risk factors of 0.87 (95\% CI, 0.83-0.91), which was consistent among all subgroups evaluated [72]. Robust evidence on the effect of non- and pharmacological interventions on endothelial function is available, in particular with antihypertensive treatments [73]. However, only two studies suggest that postmenopausal hypertensive women [74] and patients with stable coronary artery disease [75] not responding to the interventions with an FMD improvement are at considerable higher risk of further events. In a direct comparison of different biomarkers in a cohort of 1330 intermediate-risk participants of the MESA study, FMD failed to demonstrate increased discrimination and risk classification in comparison to a standard approach [27]. However, this negative result does not put an end to the debate, since FMD reproducibility in the MESA study was quite low [27] in comparison to state-of-the art approaches [76,77], stressing even more the importance of a correct methodology when approaching this technique.
FMD implies the measurement of brachial artery diameter before inflation (to $200-300 \mathrm{mmHg}$ ) and after release ( 5 minutes later) of a sphygmomanometer cuff placed on the forearm [78]. Despite the apparent simplicity, its application is technically challenging $[8,56,57]$. Indeed, some important caveats should be considered, for the effect of environmental or physiological influences [79] and technical variability of its measurement, which requires standardization $[8,78,80]$.

Variations in the technique, such as the position of the occluding cuff at the arm instead of the forearm may produce heterogeneous results that are less representative of local NO activity $[8,57]$, although possibly with the same prognostic significance [81]

The application of a rigorous methodology is able to reduce FMD variability in single center [82] and multicenter studies $[76,77]$. This comprises certified operator training [78] and defined experimental settings, including adjustable stereotactic probe-holding device and automated computer-assisted brachial artery measurements [83,84], that should be implemented in all FMD laboratories. In particular, automated real-time systems for diameter measurement are able to enhance reliability of FMD (Figure 3 ), by reducing the number of rejected examinations due to poor quality and/or instability of the images $[76,85]$ and improving operator's learning curve during training and certification [86]. 
Although the FMD methodology was set up more than 20 years ago, it is still evolving in terms of study protocol, variables considered and mathematical analysis. Alternative computation of FMD, independent of diameter, has been recently suggested [87], since the larger is the diameter, the smaller are the relative percent changes [80]. The issue of the assessment of endothelial function not only in the hyperemic state has been also introduced by measuring vasoconstriction during cuff inflation (low-flow-mediated constriction, FMC) particularly at the level of the radial artery [88]. Another important aspect that is gaining growing attention is the acquisition of stimulus for FMD itself, such as the reactive hyperemic flow, and the induced shear stress, which might be an important measure of peripheral microvascular function $[80,89,90]$. Finally, the evaluation of endothelium-independent dilator response should be always tested by the administration of low-dose sublingual nitroglycerine [91], to exclude the possibility that altered smooth muscle cell contractility may influence the endothelium-dependent response. Furthermore, the evaluation of smooth muscle cell function as part of the FMD protocol might also convey additional information about vascular health in patients with $\mathrm{CV}$ risk factors and disease [92].

\section{Conclusions}

Prevention of $\mathrm{CV}$ disease requires risk stratification and treatment of classical risk factors, such as smoking, hypertension hypercholesterolemia and diabetes. Nevertheless, classic risk stratification might be not sufficient to provide an accurate estimate of probability of future CV events.

Vascular biomarkers, which are parameters of subclinical cardiovascular disease, could increase the estimation of the individual cardiovascular risk and improve strategies for effective prevention.

Several vascular markers obtained by ultrasound and other non-invasive techniques have been proposed for this aim. Greater evidence is available for increased C-IMT and cf-PWV, which are able to improve risk reclassification and can be used to identify subclinical target organ damage. FMD only recently has reached an adequate level of methodological standardization to be proposed as surrogate endpoint in clinical trials. A solid methodology will allow to verify the intriguing hypothesis that assessment of changes in vascular biomarkers after therapy might relate to the development subclinical target organ damage or events in future clinical trials.

\section{Competing interests}

Elisabetta Bianchini, Francesco Faita and Lorenzo Ghuadoni are co-founders councilors of QUIPU s.r.l., Pisa, ITALY.

\section{Authors' contribution}

RMB and EB drafted the manuscript. FF, ST and LG reviewed the manuscript. All authors read and approved the final manuscript.

\section{Author details}

'Institute of Clinical Physiology, National Research Council, Pisa, Italy. ${ }^{2}$ Department of Clinical \& Experimental Medicine, University of Pisa, Via Roma, 67560110 Pisa, Italy.

Received: 16 July 2014 Accepted: 18 August 2014 Published: 23 August 2014

\section{References}

1. Ezzati M, Lopez AD, Rodgers A, Vander Hoorn S, Murray CJ: Selected major risk factors and global and regional burden of disease. Lancet 2002. 360(9343):1347-1360.

2. Wang TJ: Assessing the role of circulating, genetic, and imaging biomarkers in cardiovascular risk prediction. Circulation 2011, 123(5):551-565

3. Greenland P, Alpert JS, Beller GA, Benjamin EJ, Budoff MJ, Fayad ZA, Foster E, Hlatky MA, Hodgson JM, Kushner FG, Lauer MS, Shaw LJ, Smith SC Jr, Taylor AJ, Weintraub WS, Wenger NK, Jacobs AK, Anderson JL, Albert N, Buller CE, Creager MA, Ettinger SM, Guyton RA, Halperin JL, Hochman JS, Nishimura R, Ohman EM, Page RL, Stevenson WG, Tarkington LG, et al: 2010 ACCF/AHA guideline for assessment of cardiovascular risk in asymptomatic adults: a report of the American College of Cardiology Foundation/American Heart Association Task Force on Practice Guidelines. J Am Coll Cardiol 2010, 56(25):e50-103.

4. Mancia G, Fagard R, Narkiewicz K, Redon J, Zanchetti A, Bohm M, Christiaens T, Cifkova R, De Backer G, Dominiczak A, Galderisi M, Grobbee $D E$, Jaarsma T, Kirchhof P, Kjeldsen SE, Laurent S, Manolis AJ, Nilsson PM, Ruilope LM, Schmieder RE, Sirnes PA, Sleight P, Viigimaa M, Waeber B, Zannad F: 2013 ESH/ESC Guidelines for the management of arterial hypertension: the Task Force for the management of arterial hypertension of the European Society of Hypertension (ESH) and of the European Society of Cardiology (ESC). J Hypertens 2013, 31(7):1281-1357.

5. Nilsson PM, Boutouyrie P, Cunha P, Kotsis V, Narkiewicz K, Parati G, Rietzschel E, Scuteri A, Laurent S: Early vascular ageing in translation: from laboratory investigations to clinical applications in cardiovascular prevention. J Hypertens 2013, 31(8):1517-1526.

6. O'Leary DH, Bots ML: Imaging of atherosclerosis: carotid intima-media thickness. Eur Heart J 2010, 31(14):1682-1689.

7. Laurent $\mathrm{S}$, Alivon M, Beaussier H, Boutouyrie P: Aortic stiffness as a tissue biomarker for predicting future cardiovascular events in asymptomatic hypertensive subjects. Ann Med 2012, 44(Suppl 1):S93-97.

8. Charakida M, Masi S, Luscher TF, Kastelein JJ, Deanfield JE: Assessment of atherosclerosis: the role of flow-mediated dilatation. Eur Heart I 2010, 31(23):2854-2861.

9. Flammer AJ, Anderson T, Celermajer DS, Creager MA, Deanfield J, Ganz P, Hamburg NM, Luscher TF, Shechter M, Taddei S, Vita JA, Lerman A: The assessment of endothelial function: from research into clinical practice. Circulation 2012, 126(6):753-767.

10. Chambless LE, Heiss G, Folsom AR, Rosamond W, Szklo M, Sharrett AR, Clegg LX: Association of coronary heart disease incidence with carotid arterial wall thickness and major risk factors: the Atherosclerosis Risk in Communities (ARIC) Study, 1987-1993. Am J Epidemiol 1997, 146(6):483-494.

11. O'Leary DH, Polak JF, Kronmal RA, Manolio TA, Burke GL, Wolfson SK Jr: Carotid-artery intima and media thickness as a risk factor for myocardial infarction and stroke in older adults. Cardiovascular Health Study Collaborative Research Group. N Engl J Med 1999, 340(1):14-22.

12. Vlachopoulos C, Aznaouridis K, Stefanadis C: Prediction of cardiovascular events and all-cause mortality with arterial stiffness: a systematic review and meta-analysis. J Am Coll Cardiol 2010, 55(13):1318-1327.

13. Ben-Shlomo Y, Spears M, Boustred C, May M, Anderson SG, Benjamin EJ, Boutouyrie P, Cameron J, Chen CH, Cruickshank JK, Hwang SJ, Lakatta EG, Laurent S, Maldonado J, Mitchell G, Najjar S, Newman AB, Ohishi M, Pannier B, Pereira T, Vasan RS, Shokawa T, Sutton-Tyrell K, Verbeke F, Wang KL, Webb DJ, Willum Hansen T, Zoungas S: Aortic pulse wave velocity improves cardiovascular event prediction: an individual participant meta-analysis of prospective observational data from 17,635 subjects. J Am Coll Cardiol 2014, 63(7):636-646.

14. Stein JH, Korcarz CE, Hurst RT, Lonn E, Kendall CB, Mohler ER, Najiar SS, Rembold CM, Post WS: Use of carotid ultrasound to identify subclinical vascular disease and evaluate cardiovascular disease risk: a consensus statement from the American Society of Echocardiography Carotid 
Intima-Media Thickness Task Force. Endorsed by the Society for Vascular Medicine. J Am Soc Echocardiogr 2008, 21(2):93-111. quiz 189-190.

15. Salonen JT, Salonen R: Ultrasound B-mode imaging in observational studies of atherosclerotic progression. Circulation 1993, 87(3 Suppl):1156-65.

16. Paul TK, Srinivasan SR, Wei C, Li S, Bhuiyan AR, Bond MG, Tang R, Berenson GS: Cardiovascular risk profile of asymptomatic healthy young adults with increased femoral artery intima-media thickness: The Bogalusa Heart Study. Am J Med Sci 2005, 330(3):105-110.

17. Oren A, Vos LE, Uiterwaal CS, Grobbee DE, Bots ML: Cardiovascular risk factors and increased carotid intima-media thickness in healthy young adults: the Atherosclerosis Risk in Young Adults (ARYA) Study. Arch Intern Med 2003, 163(15):1787-1792.

18. Geroulakos G, O'Gorman DJ, Kalodiki E, Sheridan DJ, Nicolaides AN: The carotid intima-media thickness as a marker of the presence of severe symptomatic coronary artery disease. Eur Heart J 1994, 15(6):781-785.

19. Amato M, Montorsi P, Ravani A, Oldani E, Galli S, Ravagnani PM, Tremoli E, Baldassarre D: Carotid intima-media thickness by B-mode ultrasound as surrogate of coronary atherosclerosis: correlation with quantitative coronary angiography and coronary intravascular ultrasound findings. Eur Heart J 2007, 28(17):2094-2101.

20. Hodis HN, Mack WJ, LaBree L, Selzer RH, Liu CR, Liu CH, Azen SP: The role of carotid arterial intima-media thickness in predicting clinical coronary events. Ann Intern Med 1998, 128(4):262-269.

21. Bots ML, Hoes AW, Koudstaal PJ, Hofman A, Grobbee DE: Common carotid intima-media thickness and risk of stroke and myocardial infarction: the Rotterdam Study. Circulation 1997, 96(5):1432-1437.

22. Chambless LE, Folsom AR, Clegg LX, Sharrett AR, Shahar E, Nieto FJ, Rosamond WD, Evans G: Carotid wall thickness is predictive of incident clinical stroke: the Atherosclerosis Risk in Communities (ARIC) study. Am J Epidemiol 2000, 151(5):478-487.

23. Rosvall M, Janzon L, Berglund G, Engstrom G, Hedblad B: Incident coronary events and case fatality in relation to common carotid intima-media thickness. J Intern Med 2005, 257(5):430-437.

24. Rosvall M, Janzon L, Berglund G, Engstrom G, Hedblad B: Incidence of stroke is related to carotid IMT even in the absence of plaque. Atherosclerosis 2005, 179(2):325-331.

25. Lorenz MW, von Kegler S, Steinmetz H, Markus HS, Sitzer M: Carotid intimamedia thickening indicates a higher vascular risk across a wide age range: prospective data from the Carotid Atherosclerosis Progression Study (CAPS). Stroke 2006, 37(1):87-92.

26. Peters SA, den Ruijter HM, Bots ML, Moons KG: Improvements in risk stratification for the occurrence of cardiovascular disease by imaging subclinical atherosclerosis: a systematic review. Heart 2012, 98(3):177-184.

27. Yeboah J, McClelland RL, Polonsky TS, Burke GL, Sibley CT, O'Leary D, Carr JJ, Goff DC, Greenland P, Herrington DM: Comparison of novel risk markers for improvement in cardiovascular risk assessment in intermediate-risk individuals. JAMA 2012, 308(8):788-795.

28. Goff DC Jr, Lloyd-Jones DM, Bennett G, Coady S, D'Agostino RB, Gibbons R Greenland P, Lackland DT, Levy D, O'Donnell CJ, Robinson JG, Schwartz JS, Shero ST, Smith SC Jr, Sorlie P, Stone NJ, Wilson PW: 2013 ACC/AHA Guideline on the Assessment of Cardiovascular Risk: A Report of the American College of Cardiology/American Heart Association Task Force on Practice Guidelines. Circulation 2014, 129(25 Suppl 2):S49-73.

29. Finn AV, Kolodgie FD, Virmani R: Correlation between carotid intimal/ medial thickness and atherosclerosis: a point of view from pathology. Arterioscler Thromb Vasc Biol 2010, 30(2):177-181.

30. Polak JF, Pencina MJ, O'Leary DH, D'Agostino RB: Common carotid artery intima-media thickness progression as a predictor of stroke in multiethnic study of atherosclerosis. Stroke 2011, 42(11):3017-3021.

31. Wikstrand J: Methodological considerations of ultrasound measurement of carotid artery intima-media thickness and lumen diameter. Clin Physiol Funct Imaging 2007, 27(6):341-345.

32. Polak JF, Person SD, Wei GS, Godreau A, Jacobs DR Jr, Harrington A, Sidney S, O'Leary DH: Segment-specific associations of carotid intimamedia thickness with cardiovascular risk factors: the Coronary Artery Risk Development in Young Adults (CARDIA) study. Stroke 2010, 41(1):9-15.

33. Dogan S, Plantinga Y, Crouse JR 3rd, Evans GW, Raichlen JS, O'Leary DH, Palmer MK, Grobbee DE, Bots ML: Algorithms to measure carotid intimamedia thickness in trials: a comparison of reproducibility, rate of progression and treatment effect. J Hypertens 2011, 29(11):2181-2193.
34. Espeland MA, O'Leary DH, Terry JG, Morgan T, Evans G, Mudra H: Carotid intimal-media thickness as a surrogate for cardiovascular disease events in trials of HMG-CoA reductase inhibitors. Curr Control Trials Cardiovasc Med 2005, 6(1):3.

35. Costanzo P, Perrone-Filardi P, Vassallo E, Paolillo S, Cesarano P, Brevetti G, Chiariello M: Does carotid intima-media thickness regression predict reduction of cardiovascular events? A meta-analysis of 41 randomized trials. J Am Coll Cardiol 2010, 56(24):2006-2020

36. Brands PJ, Hoeks AP, Willigers J, Willekes C, Reneman RS: An integrated system for the non-invasive assessment of vessel wall and hemodynamic properties of large arteries by means of ultrasound. Eur J Ultrasound 1999, 9(3):257-266.

37. Laurent S, Cockcroft J, Van Bortel L, Boutouyrie P, Giannattasio C, Hayoz D, Pannier B, Vlachopoulos C, Wilkinson I, Struijker-Boudier H: Expert consensus document on arterial stiffness: methodological issues and clinical applications. Eur Heart J 2006, 27(21):2588-2605. Epub 2006 Sep 2525.

38. Bianchini E, Bozec E, Gemignani V, Faita F, Giannarelli C, Ghiadoni L, Demi $M$, Boutouyrie $P$, Laurent $S$ : Assessment of carotid stiffness and intimamedia thickness from ultrasound data: comparison between two methods. J Ultrasound Med 2010, 29(8):1169-1175.

39. Molinari F, Zeng G, Suri JS: A state of the art review on intima-media thickness (IMT) measurement and wall segmentation techniques for carotid ultrasound. Comput Methods Prog Biomed 2010, 100(3):201-221.

40. Touboul PJ, Hennerici MG, Meairs S, Adams H, Amarenco P, Bornstein N, Csiba L, Desvarieux M, Ebrahim S, Fatar M, Hernandez Hernandez R, Jaff M, Kownator S, Prati P, Rundek T, Sitzer M, Schminke U, Tardif JC, Taylor A Vicaut E, Woo KS, Zannad F: Zureik M: Mannheim carotid intima-media thickness consensus (2004-2006). An update on behalf of the Advisory Board of the 3rd and 4th Watching the Risk Symposium, 13th and 15th European Stroke Conferences, Mannheim, Germany, 2004, and Brussels, Belgium, 2006. Cerebrovasc Dis 2007, 23(1):75-80.

41. Rossi AC, Brands PJ, Hoeks AP: Nonlinear processing in B-mode ultrasound affects carotid diameter assessment. Ultrasound Med Biol 2009, 35(5):736-747.

42. Engelen L, Ferreira I, Stehouwer CD, Boutouyrie P, Laurent S: Reference intervals for common carotid intima-media thickness measured with echotracking: relation with risk factors. Eur Heart J 2013, 34(30):2368-2380.

43. Paini A, Boutouyrie P, Calvet D, Tropeano Al, Laloux B, Laurent S: Carotid and aortic stiffness: determinants of discrepancies. Hypertension 2006, 47(3):371-376

44. Giannarelli C, Bianchini E, Bruno RM, Magagna A, Landini L, Faita F, Gemignani V, Penno G, Taddei S, Ghiadoni L: Local carotid stiffness and intima-media thickness assessment by a novel ultrasound-based system in essential hypertension. Atherosclerosis 2012, 223(2):372-377.

45. Lakatta EG: Arterial and cardiac aging: major shareholders in cardiovascular disease enterprises: Part III: cellular and molecular clues to heart and arterial aging. Circulation 2003, 107(3):490-497.

46. Chiu YC, Arand PW, Shroff SG, Feldman T, Carroll JD: Determination of pulse wave velocities with computerized algorithms. Am Heart J 1991, 121(5):1460-1470

47. Van Bortel LM, Duprez D, Starmans-Kool MJ, Safar ME, Giannattasio C, Cockcroft J, Kaiser DR, Thuillez C: Clinical applications of arterial stiffness, Task Force III: recommendations for user procedures. Am J Hypertens 2002, 15(5):445-452

48. Van Bortel LM, Laurent S, Boutouyrie P, Chowienczyk P, Cruickshank JK, De Backer T, Filipovsky J, Huybrechts S, Mattace-Raso FU, Protogerou AD, Schillaci G, Segers P, Vermeersch S, Weber T: Expert consensus document on the measurement of aortic stiffness in daily practice using carotidfemoral pulse wave velocity. J Hypertens 2012, 30(3):445-448.

49. Asmar R, Benetos A, Topouchian J, Laurent P, Pannier B, Brisac AM, Target R, Levy Bl: Assessment of arterial distensibility by automatic pulse wave velocity measurement. Assessment of arterial distensibility by automatic pulse wave velocity measurement. Validation and clinical application studies 1995, 26(3):485-490.

50. Millasseau SC, Guigui FG, Kelly RP, Prasad K, Cockcroft JR, Ritter JM, Chowienczyk PJ: Noninvasive assessment of the digital volume pulse. Comparison with the peripheral pressure pulse. Hypertension 2000 36(6):952-956.

51. Sugawara J, Hayashi K, Yokoi T, Cortez-Cooper MY, DeVan AE, Anton MA, Tanaka $\mathrm{H}$ : Brachial-ankle pulse wave velocity: an index of central arterial stiffness? J Hum Hypertens 2005, 19(5):401-406. 
52. Mattace-Raso F, Hofman A, Verwoert GC, Wittemana JC, Wilkinson I, Cockcroft J, McEniery C, Yasmin, Laurent S, Boutouyrie P, Bozec E, Hansen TW, Torp-Pedersen C, Ibsen H, Jeppesen J, Vermeersch SJ, Rietzschel E, De Buyzere M, Gillebert TC, Van Bortel L, Segers P, Vlachopoulos C, Aznaouridis C, Stefanadis C, Benetos A, Labat C, Lacolley P, Stehouwer C, Nijpels G, Dekker JM, et al: Determinants of pulse wave velocity in healthy people and in the presence of cardiovascular risk factors: 'establishing normal and reference values'. Eur Heart J 2010, 31(19):2338-2350.

53. Laurent $S$, Briet $M$, Boutouyrie P: Arterial stiffness as surrogate end point: needed clinical trials. Hypertension 2012, 60(2):518-522

54. Luscher TF, Barton M: Biology of the endothelium. Clin Cardiol 1997, 20(11 Suppl 2): :1-3-10.

55. Ross R: Atherosclerosis-an inflammatory disease. N Engl J Med 1999, 340(2):115-126.

56. Deanfield J, Donald A, Ferri C, Giannattasio C, Halcox J, Halligan S, Lerman A, Mancia G, Oliver JJ, Pessina AC, Rizzoni D, Rossi GP, Salvetti A, Schiffrin EL, Taddei S, Webb DJ: Endothelial function and dysfunction. Part I: Methodological issues for assessment in the different vascular beds: a statement by the Working Group on Endothelin and Endothelial Factors of the European Society of Hypertension. J Hypertens 2005, 23(1):7-17.

57. Deanfield JE, Halcox JP, Rabelink TJ: Endothelial function and dysfunction: testing and clinical relevance. Circulation 2007, 115(10):1285-1295.

58. Celermajer DS, Sorensen KE, Gooch VM, Spiegelhalter DJ, Miller OI, Sullivan ID, Lloyd JK, Deanfield JE: Non-invasive detection of endothelial dysfunction in children and adults at risk of atherosclerosis. Lancet 1992 340(8828):1111-1115.

59. Ghiadoni L, Versari D, Magagna A, Kardasz I, Plantinga Y, Giannarelli C, Taddei S, Salvetti A: Ramipril dose-dependently increases nitric oxide availability in the radial artery of essential hypertension patients. $J$ Hypertens 2007, 25(2):361-366

60. Green DJ, Dawson EA, Groenewoud HM, Jones H, Thijssen DH: Is flowmediated dilation nitric oxide mediated?: A meta-analysis. Hypertension 2014, 63(2):376-382.

61. Hashimoto M, Eto M, Akishita M, Kozaki K, Ako J, lijima K, Kim S, Toba K, Yoshizumi M, Ouchi Y: Correlation between flow-mediated vasodilatation of the brachial artery and intima-media thickness in the carotid artery in men. Arterioscler Thromb Vasc Biol 1999, 19(11):2795-2800.

62. Juonala M, Viikari JS, Laitinen T, Marniemi J, Helenius H, Ronnemaa T, Raitakari OT: Interrelations between brachial endothelial function and carotid intima-media thickness in young adults: the cardiovascular risk in young Finns study. Circulation 2004, 110(18):2918-2923.

63. Halcox JP, Donald AE, Ellins E, Witte DR, Shipley MJ, Brunner EJ, Marmot MG, Deanfield JE: Endothelial function predicts progression of carotid intimamedia thickness. Circulation 2009, 119(7):1005-1012.

64. Rossi R, Nuzzo A, Olaru Al, Origliani G, Modena MG: Endothelial function affects early carotid atherosclerosis progression in hypertensive postmenopausal women. J Hypertens 2011, 29(6):1136-1144.

65. Patti G, Pasceri V, Melfi R, Goffredo C, Chello M, D'Ambrosio A, Montesanti R, Di Sciascio G: Impaired flow-mediated dilation and risk of restenosis in patients undergoing coronary stent implantation. Circulation 2005, 111(1):70-75.

66. Gokce N, Keaney JF Jr, Hunter LM, Watkins MT, Menzoian JO, Vita JA: Risk stratification for postoperative cardiovascular events via noninvasive assessment of endothelial function: a prospective study. Circulation 2002, 105(13):1567-1572.

67. Neunteufl T, Heher S, Katzenschlager R, Wolfl G, Kostner K, Maurer G, Weidinger $F$ : Late prognostic value of flow-mediated dilation in the brachial artery of patients with chest pain. Am J Cardiol 2000, 86(2):207-210

68. Rossi R, Nuzzo A, Origliani G, Modena MG: Prognostic role of flowmediated dilation and cardiac risk factors in post-menopausal women. J Am Coll Cardiol 2008, 51(10):997-1002.

69. Muiesan ML, Salvetti M, Paini A, Monteduro C, Galbassini G, Poisa P, Porteri E, Agabiti-Rosei C, Paderno V, Belotti E, Rizzoni D, Castellano M, AgabitiRosei E: Prognostic role of flow-mediated dilatation of the brachial artery in hypertensive patients. J Hypertens 2008, 26(8):1612-1618.

70. Yeboah J, Crouse JR, Hsu FC, Burke GL, Herrington DM: Brachial flowmediated dilation predicts incident cardiovascular events in older adults: the Cardiovascular Health Study. Circulation 2007, 115(18):2390-2397.

71. Yeboah J, Folsom AR, Burke GL, Johnson C, Polak JF, Post W, Lima JA, Crouse JR, Herrington DM: Predictive value of brachial flow-mediated dilation for incident cardiovascular events in a population-based study: the multi-ethnic study of atherosclerosis. Circulation 2009, 120(6):502-509.

72. Inaba $Y$, Chen JA, Bergmann SR: Prediction of future cardiovascular outcomes by flow-mediated vasodilatation of brachial artery: a metaanalysis. Int J Cardiovasc Imaging 2010, 26(6):631-640.

73. Ghiadoni L, Taddei S, Virdis A: Hypertension and endothelial dysfunction: therapeutic approach. Curr Vasc Pharmacol 2012, 10(1):42-60.

74. Modena MG, Bonetti L, Coppi F, Bursi F, Rossi R: Prognostic role of reversible endothelial dysfunction in hypertensive postmenopausal women. J Am Coll Cardiol 2002, 40(3):505-510.

75. Kitta Y, Obata JE, Nakamura T, Hirano M, Kodama Y, Fujioka D, Saito Y, Kawabata K, Sano K, Kobayashi T, Yano T, Nakamura K, Kugiyama K: Persistent impairment of endothelial vasomotor function has a negative impact on outcome in patients with coronary artery disease. J Am Coll Cardiol 2009, 53(4):323-330.

76. Ghiadoni L, Faita F, Salvetti M, Cordiano C, Biggi A, Puato M, Di Monaco A, De Siati L, Volpe M, Ambrosio G, Gemignani V, Muiesan ML, Taddei S, Lanza GA, Cosentino F: Assessment of flow-mediated dilation reproducibility: a nationwide multicenter study. J Hypertens 2012, 30(7):1399-1405.

77. Charakida M, de Groot E, Loukogeorgakis SP, Khan T, Luscher T, Kastelein JJ, Gasser T, Deanfield JE: Variability and reproducibility of flow-mediated dilatation in a multicentre clinical trial. Eur Heart J 2013, 34(45):3501-3507.

78. Corretti MC, Anderson TJ, Benjamin EJ, Celermajer D, Charbonneau F, Creager MA, Deanfield J, Drexler H, Gerhard-Herman M, Herrington D, Vallance P, Vita J, Vogel R: Guidelines for the ultrasound assessment of endothelial-dependent flow-mediated vasodilation of the brachial artery: a report of the International Brachial Artery Reactivity Task Force. J Am Coll Cardiol 2002, 39(2):257-265.

79. Ghiadoni L, Donald AE, Cropley M, Mullen MJ, Oakley G, Taylor M, O'Connor G, Betteridge J, Klein N, Steptoe A, Deanfield JE: Mental stress induces transient endothelial dysfunction in humans. Circulation 2000, 102(20):2473-2478

80. Thijssen DH, Black MA, Pyke KE, Padilla J, Atkinson G, Harris RA, Parker B, Widlansky ME, Tschakovsky ME, Green DJ: Assessment of flow-mediated dilation in humans: a methodological and physiological guideline. Am J Physiol Heart Circulatory Physiol 2011, 300(1):H2-12.

81. Green DJ, Jones H, Thijssen D, Cable NT, Atkinson G: Flow-mediated dilation and cardiovascular event prediction: does nitric oxide matter? Hypertension 2011, 57(3):363-369.

82. Donald AE, Halcox JP, Charakida M, Storry C, Wallace SM, Cole TJ, Friberg P, Deanfield JE: Methodological approaches to optimize reproducibility and power in clinical studies of flow-mediated dilation. J Am Coll Cardiol 2008 51(20):1959-1964.

83. Gemignani V, Faita F, Ghiadoni L, Poggianti E, Demi M: A system for realtime measurement of the brachial artery diameter in B-mode ultrasound images. IEEE Trans Med Imaging 2007, 26(3):393-404.

84. Gemignani V, Bianchini E, Faita F, Giannarelli C, Plantinga Y, Ghiadoni L, Demi M: Ultrasound measurement of the brachial artery flow-mediated dilation without ECG gating. Ultrasound Med Biol 2008, 34(3):385-391.

85. Luscher TF, Taddei S, Kaski JC, Jukema JW, Kallend D, Munzel T, Kastelein JJ, Deanfield JE: Vascular effects and safety of dalcetrapib in patients with or at risk of coronary heart disease: the dal-VESSEL randomized clinical trial. Eur Heart J 2012, 33(7):857-865.

86. Faita F, Masi S, Loukogeorgakis S, Gemignani V, Okorie M, Bianchini E, Charakida M, Demi M, Ghiadoni L, Deanfield JE: Comparison of two automatic methods for the assessment of brachial artery flow-mediated dilation. J Hypertens 2011, 29(1):85-90.

87. Atkinson G, Batterham AM: Allometric scaling of diameter change in the original flow-mediated dilation protocol. Atherosclerosis 2013, 226(2):425-427.

88. Gori T, Dragoni S, Lisi M, Di Stolfo G, Sonnati S, Fineschi M, Parker JD: Conduit artery constriction mediated by low flow a novel noninvasive method for the assessment of vascular function. J Am Coll Cardiol 2008, 51(20):1953-1958.

89. Mitchell GF, Vita JA, Larson MG, Parise H, Keyes MJ, Warner E, Vasan RS, Levy D, Benjamin EJ: Cross-sectional relations of peripheral microvascular function, cardiovascular disease risk factors, and aortic stiffness: the Framingham Heart Study. Circulation 2005, 112(24):3722-3728.

90. Anderson TJ, Charbonneau F, Title LM, Buithieu J, Rose MS, Conradson H, Hildebrand K, Fung M, Verma S, Lonn EM: Microvascular function predicts cardiovascular events in primary prevention: long-term results from the 
Firefighters and Their Endothelium (FATE) study. Circulation 2011, 123(2):163-169.

91. Ghiadoni L, Huang Y, Magagna A, Buralli S, Taddei S, Salvetti A: Effect of acute blood pressure reduction on endothelial function in the brachial artery of patients with essential hypertension. J Hypertens 2001, 19(3 Pt 2):547-551.

92. Bruno RM, Ghiadoni L: Vascular smooth muscle function: defining the diabetic vascular phenotype. Diabetologia 2013, 56(10):2107-2109.

doi:10.1186/1476-7120-12-34

Cite this article as: Bruno et al:: Intima media thickness, pulse wave velocity, and flow mediated dilation. Cardiovascular Ultrasound 2014 12:34

\section{Submit your next manuscript to BioMed Central and take full advantage of:}

- Convenient online submission

- Thorough peer review

- No space constraints or color figure charges

- Immediate publication on acceptance

- Inclusion in PubMed, CAS, Scopus and Google Scholar

- Research which is freely available for redistribution 